\title{
Rectal Foreign-Body Retained by Self-Sexual Stimulation: A Case of a 12 Year-Old Boy
}

\author{
Seksüel Amaçla Meydana Gelen Rektal Yabancı Cisim: On İki Yaşında Erkek Olgu
}

\author{
Mesut Okur', Adem Küçük², Aybars Özkan', Murat Kaya², Ali Kemal Taşkın \\ 'Department of Pediatrics, Faculty of Medicine, Düzce University, Düzce, Turkey \\ 2Department of Pediatric Surgery, Faculty of Medicine, Düzce University, Düzce, Turkey \\ ${ }^{3}$ Department of General Surgery, Faculty of Medicine, Düzce University, Düzce, Turkey
}

\begin{abstract}
Although a rectal foreign body (FB) usually occurs in children with iatrogenic causes, it may be seen in older children due to an object used for sexual stimulation. The extraction process of retained rectal FBs can require various interventions including laparotomy. A 12-year-old male was admitted to the emergency department with complaints of abdominal and anal pain. A plain abdominal $x$-ray revealed a retained rectal $F B$. The foreign object was extracted manually from the rectum in the emergency intervention room. Initially, the patient said that he had swallowed the FB; however, after a detailed inquiry it was determined that he was using the object for self-satisfaction. In this case report, we emphasized that rectal FBs could also be readily removed by digital rectal manipulation without the need for general anesthesia and this patient was very young with a rectal FB.
\end{abstract}

Keywords: Rectal foreign body, masturbation, digital rectal examination, adolescent

Received: 07.02.2012 Accepted: 19.03.2012

\section{ÖZET}

Rektal yabancı cisim; çocuklarda genellikle iatrojenik nedenlerle meydana gelmekle birlikte büyük çocuklarda seksüel amaçla kullanılan bir nesne sebebiyle de oluşabilir. Yabancı cismin çıkarılma işlemi laparotomiyi de içerebilen çeşitli müdahaleleri gerektirir. On iki yaşında erkek hasta karın ağrısı ve makatta acıma yakınmalarıyla acil servise başvurdu. Çekilen ayakta karın grafisinde rektumda yabancı cisim saptandı. Acil müdahale odasında rektal tuşe yardımı ile yabancı cisim çıkartıldı. Başlangıçta hasta bu cismi yuttuğunu söylediyse de ayrıntılı sorgulama sonucu kendi kendine seksüel amaçla kullandığı anlaşıldı. Bu olgu sunumunda hastanın oldukça küçük yaşta olduğunu ve rektal yabancı cismin genel anesteziye gereksinim duyulmaksızın rektal müdahale ile de çıkarılabileceğini vurgulamak istedik.

Anahtar Kelimeler: Rektal yabancı cisim, mastürbasyon, rektal tuşe, adolesan

Geliş Tarihi: 07.02.2012 Kabul Tarihi: 19.03.2012

\section{Introduction}

The incidence of rectal foreign bodies (FBs) is unknown. The incidence of retained rectal FBs has been rising because of increasing use of different objects for anal sex (1). A patient may be using the rectal FB for sexual satisfaction. The age of patients with retained rectal FBs ranges from 14 to 76 years (2). We present a 12-year-old boy who inserted a FB rectally for self-satisfaction. This patient is the youngest such case in the literature so far.

\section{Case Report}

A 12-year-old boy was admitted to the emergency department because an empty perfume bottle had been inserted into his rectum 6 hours earlier. He was referred to pediatric surgery by a pediatrician because of abdominal and anal pain. He did not have any other signs except the pain. An abdominal X-ray revealed a bottle-shaped object in the rectum. He denied having been sexually abused, and he soon confessed that he used the object for self-satisfaction. He complained of minor abdominal and anal pain. The abdominal X-ray showed the size and position of the bottle without any signs of free abdominal air (Figure 1). Abdominal and ano-rectal examinations were normal. The bottle was palpated about $3 \mathrm{~cm}$ from the anus via a rectal digital examination. The FB was clamped with a blunt clamp and extracted (Figure 2). The maximum diameter of the bottle was $52 \mathrm{~mm}$. 


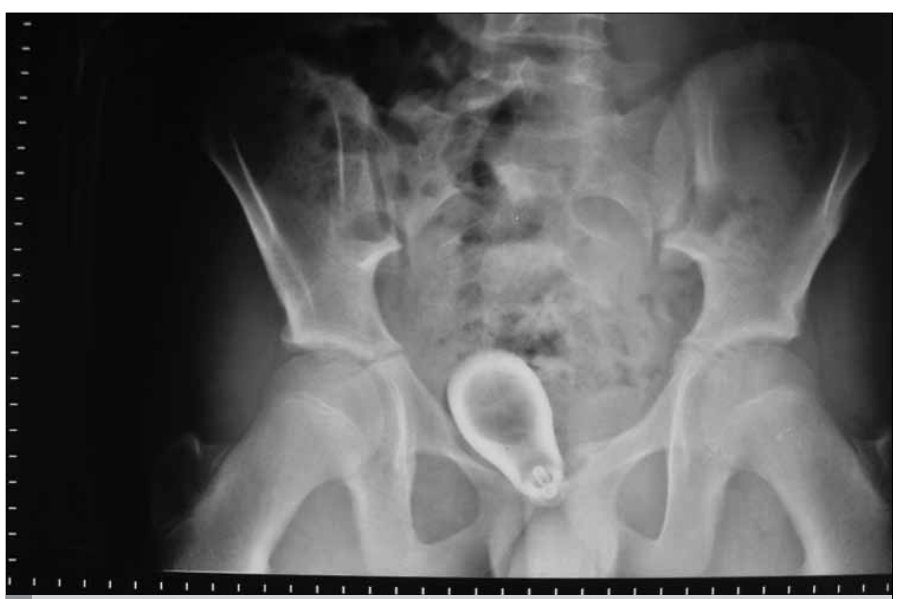

Figure 1. The bottle-shaped object as seen on the abdominal X-ray

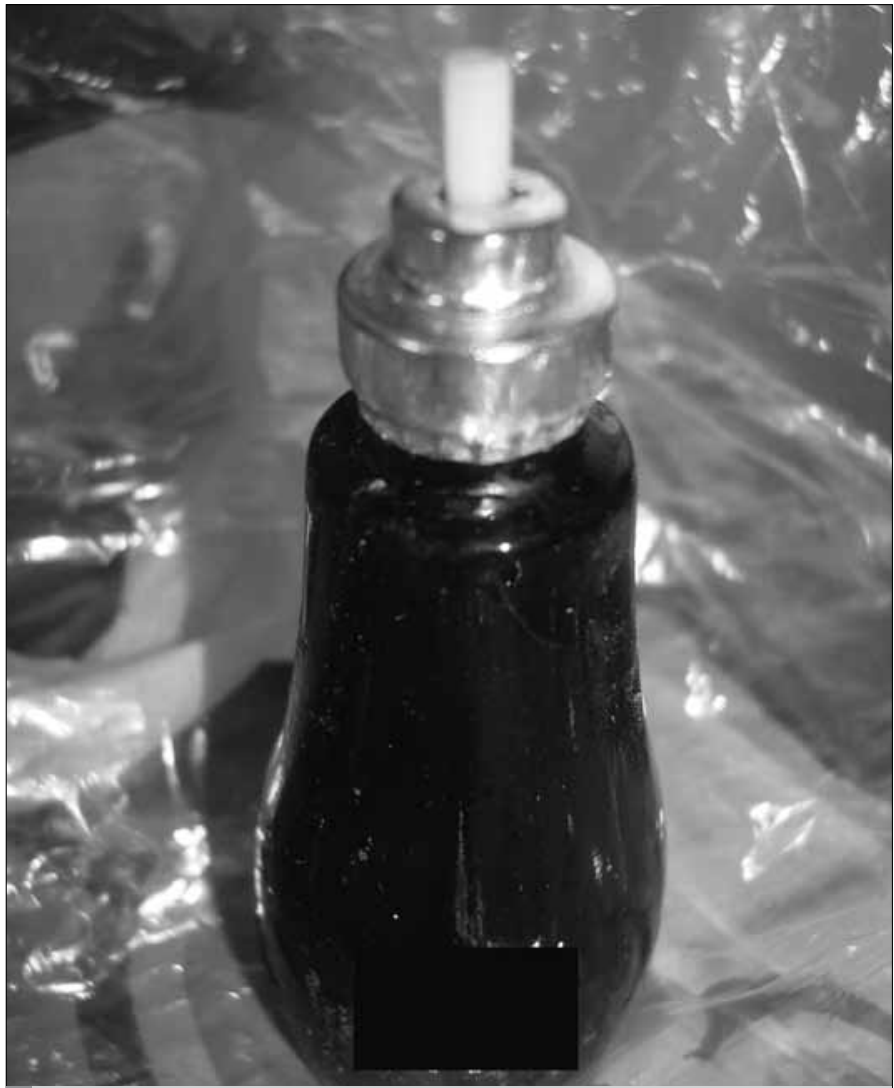

Figure 2. Extracted perfume bottle

Small mucosal lesions were found after the procedure. The patient had normal sphincter function at a 2-months follow up, and no fecal incontinence was encountered. After the extraction, the patient was advised to consult a psychiatrist, but he refused.

\section{Discussion}

Masturbation is a common form of self-satisfaction, and this activity is seen in all age groups including infancy (3). Stimulation can be performed manually or using objects or tools (4). It is frequently associated with unusual posture and movement, sweating, flushing, and tachypnea and may begin in infancy and early childhood (5). The most common methods of masturbation in adolescents and adults are pressing or rubbing the genital area or inserting an object into the anus. These objects can be hazardous, as can any rectal FB. A woman with two pencils in her bladder reported that she had inserted them into the urethra during masturbation (6).

Rectal FBs are usually reported as iatrogenic cases in children, as with thermometers $(7,8)$. There is no limit to the type of object used for rectal stimulation, including artificial phalluses, vibrators, fruits, vegetables, bottles, billiard balls, light bulbs, paperweights, and screwdrivers (9). Patients with a rectal FB are usually admitted for two reasons, one of which is that they are unable to extract the FB by themselves, and the other is perforation and acute abdominal pain (10). A rectal FB can be extracted manually or by using various forceps or vacuums (9). In the present case, the foreign object was extracted from the anus using a clamp. No significant injury occurred to the anus or mucosa, and anal tonus was minimally reduced. However, a risk of rectal perforation remained until the object was removed safely. An abdominal laparotomy may be required if the FB cannot be easily extracted (11).

These patients often attempt to extract the object before presenting to the ED. Admittance to the hospital is almost always delayed due to the inevitable embarrassment. The important points are to respect the privacy of these patients and to determine the shape and location of the FB, the need for surgery, and the appropriate technique for extraction. Humiliating expressions should be avoided, as illustrated elsewhere (10). Certainly, psychiatric help or sexual therapy is suggested for these cases; however, most patients do not demand such psychotherapy.

\section{Conclusion}

Foreign objects are usually easily extractable through the entry site. We presented a rare case of a 12-year-old boy with a rectal FB that was extracted without general anesthesia. This seems to be a good method for extracting a FB from the rectum. We would like to emphasize that cases with retained FBs that were used for self-satisfaction are shifting to an earlier age. Thus, sex education activities should not be neglected.

\section{Conflict of interest}

No conflict of interest was declared by the authors.

\section{References}

1. Caliskan C, Makay O, Firat O, Can Karaca A, Akgun E, Korkut MA. Foreign bodies in the rectum: an analysis of 30 patients. Surg Today 2011; 41: 795-800. [CrossRef]

2. Steenvoorde P, Rovers JP, Tollenaar RA. Retained foreign body in a 14-year-old boy. J Pediatr Surg 2003; 38: 1554-6. [CrossRef]

3. Kaya A, Taşkın GA, Okur M, Bektaş MS, Çaksen H. Infantile masturbation in monozygotic twins. J Sex Med 2012; 9: 331-2. [CrossRef]

4. Based on "masturbation" in Merriam-Webster's Collegiate Dictionary, Eleventh Edition, Merriam-Webster, Inc., 2003.

5. Yang ML, Fullwood E, Goldstein J, Mink JW. Masturbation in infancy and early childhood presenting as a movement disorder: 12 cases and a review of the literature. Pediatrics 2005; 116: 1427-32. [CrossRef] 
6. Wegner HE, Franke M, Schick V. Endoscopic removal of intravesical pencils using percutaneous nephrolithotomy sheath and forceps. J Urol 1997; 157: 1842. [CrossRef]

7. Morales L, Rovira J, Mongard M, Sancho MA, Bach A. Intraspinal migration of a rectal foreign body. J Pediatr Surg 1983; 18: 634-5. [CrossRef]

8. Kural AR, Comez E, Erozenci A, Oner A, Akaydin A. Intravesical migration of a rectal foreign body. Br J Urol 1987; 60: 79. [CrossRef]
9. Elam AL, Ray VG. Sexually related trauma: a review. Ann Emerg Med 1986; 15: 576-84. [CrossRef]

10. Barone JE, Sohn N, Nealon TF Jr. Perforations and foreign bodies of the rectum: report of 28 cases. Ann Surg 1976; 184: 601-4. [CrossRef]

11. Kouraklis G, Misiakos E, Dovas N, Karatzas G, Gogas J. Management of foreign bodies of the rectum: report of 21 cases. J R Coll Surg Edinb 1997; 42: 246-7. 